\title{
Can Emissions Be Reduced Using Latent Heat of Methane in LNG Powered Heavy Vehicles?
}

\author{
Adem Uğurlu ${ }^{*}$ \\ 1* Kırklareli University, Faculty of Technology, Department of Mechatronics Engineering, Kırklareli, Turkey, (ORCID: 0000-0002-9531-3944), \\ adem.ugurlu@klu.edu.tr
}

(International Conference on Design, Research and Development (RDCONF) 2021 - 15-18 December 2021)

(DOI: 10.31590/ejosat.1041682)

ATIF/REFERENCE: Uğurlu, A. (2021). Can Emissions Be Reduced Using Latent Heat of Methane in LNG Powered Heavy Vehicles?. European Journal of Science and Technology, (32), 1066-1069.

\begin{abstract}
Liquid natural gas-powered vehicles store liquid natural gas fuel on board. When the gasification of this fuel is maintained, cooling down of the the vehicle cabin can be provided. In this study, the theoretical calculation of the savings that can be achieved if this process is done with an appropriate tool is emphasized. Since diesel fuel is used in heavy vehicles, diesel is taken as reference fuel in the calculations. How much methane is needed by the heavy vehicles that operate at various consumption values is calculated fist, then how much LNG should be evaporated for this need is found, and then, what amount of cooling this evaporating LNG could provide is computed. The results are presented in tabular form. It is seen that the proposed system can provide fuel savings with sufficient cooling, and therefore reduce emissions, especially in the vehicles mentioned.
\end{abstract}

Keywords: Air conditioning, Internal combustion engines, Liquid natural gas.

\section{LNG Yakıtlı Ağır Vasıtalarda Methanın Gizli Isısını Kullanarak Emisyonlar Düşürülebilir mi?}

$\ddot{O} \mathbf{z}$

Sıvılaştırılmış doğal gazla çalışan araçlar, sıvılaştırılmış doğal gaz yakıtını depolarlar. Bu yakıtın gazlaştırılması sağlandığında, taşıt kabininin soğutulması sağlanabilecektir. Bu çalışmada, bu işlemin uygun bir araç ile yapılması durumunda elde edilebilecek tasarrufların teorik olarak hesaplanması üzerinde durulmuştur. Ağır vasıtalarda dizel yakıtı kullanıldı ̆̆ı için hesaplamalarda dizel referans yakıt olarak alınmıştır. Öncelikle çeşitli tüketim değerinde çalışan ağır vasıtaların ne kadar metan yakacakları hesaplanmış, sonra bunun için ne kadar LNG buharlaşması gerektiği hesaplanmış ve bu buharlaşan LNG'nin hangi miktarda soğutma sağlayabileceği bulunmuştur. Sonuçlar tablo halinde sunulmuştur. Önerilen sistemin özellikle belirtilen taşıtlarda yeterli bir soğutma ile yakıt tasarrufu sağlayabileceği dolayısıyla da emisyonları azaltabileceği görülmektedir.

Anahtar Kelimeler: Klima, İçten yanmalı motorlar, Sıvılaştırılmış doğal gaz.

\footnotetext{
*Sorumlu Yazar: adem.ugurlu@klu.edu.tr
} 


\section{Introduction}

Conventional fuel sources are depleting, and the environmental effects of their utilization are very hard to ignore (Ciniviz and Köse 2011, Tüccar et al. 2013, Akar et al. 2018). There are advances in alternative fuel sources recently, and natural gas is one of those fuel sources. Vehicles are among the main areas of natural gas utilization, especially in diesel powered heavy vehicles. Liquefaction of natural gas is one of the best ways to store natural gas, thus LNG constitutes a promising part of natural gas applications. LNG is currently used for some other areas such as power generation, furnaces, fluid bed dryers, and boilers. When gasification of LNG in all of these applications is used for refrigeration purposes with an auxiliary equipment, it will save this waste energy at small costs. This study examines whether this proposed system will fully meet the vehicle AC load. AC systems are essential equipment of vehicles in terms of providing driving comfort and consequently driving safety. However, they increase fuel consumption of vehicles, and this increase can be as much as $12-20 \%$ of total consumption according to indeterminate conditions (Lambert and Jones 2006, Khayyam 2013, Javani et al. 2012). Furthermore, there is a high correlation between AC system and emission increase (Welstand et al. 2003). On the other hand, in vehicles without air conditioning, internal comfort is tried to be provided by blowing the outside air inside or opening the windows, but this is not enough. Therefore, it is important to provide cabin comfort with equipment other than a compressor air conditioner that draws power from the engine (Dincer 2007, Randaxhe et al. 2015, Linder et al. 2010). Several methods and systems have been proposed in literature. In a part of them, LNG provided cooling during its gasification in a Rankine cycle (Popov et al. 2019, Deng et al. 2004, Dispenza et al. 2009a, Liu and Guo 2011, Dispenza et al. 2009b, Jan and Ireneusz 2009). In another one (Den et al. 2004), a combined system to provide both cooling and powering ability of LNG was proposed. In this study, similar aim is investigated for LNG powered vehicles theoretically investigated. The analysis mainly depends on the fuel consumption of the vehicle and latent heat of evaporating LNG.

\section{Methodology}

The proposed system aims to use the latent heat energy of LNG to provide for both power in the engine and cooling in the cabin at the same time. The layout of the system is shown in Fig. 1 , the system consists of two main circuits: LNG and air. While the LNG circuit maintains methane for the engine of the vehicle, the air circuit supplies cooling for the vehicle cabin.

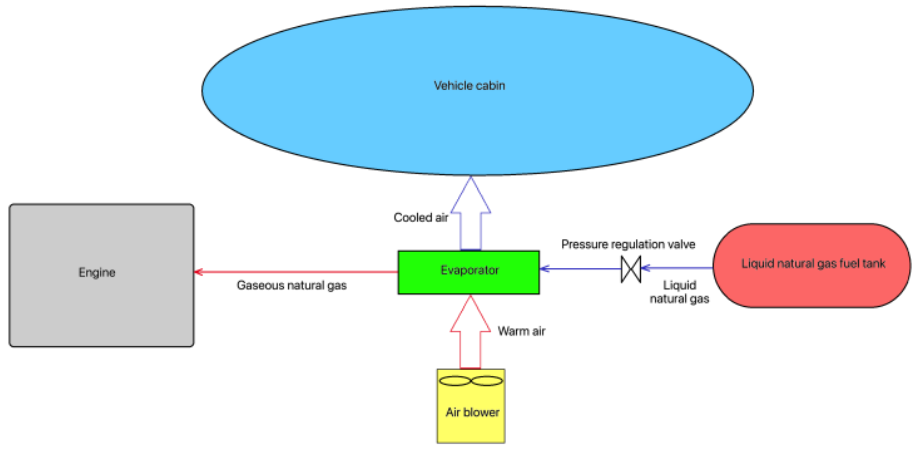

Figure 1. Layout of the system for vehicles storing $L N G$
Eqs. (1-6) show the overall calculation process of the proposed system to the LNGVs. In Eq. (1), the average diesel consumption $(\mathrm{L} / \mathrm{s})$ calculation is performed, where $\mathrm{FC}_{\mathrm{d}}(\mathrm{L} / 100$ $\mathrm{km}$ ) is determined according to the NEDC that is declared by the vehicle manufacturer accordingly. NEDC cycle takes $11,007 \mathrm{~km}$ road at a time period of $1180 \mathrm{~s}$ (Pacheco et al. 2013, Marachlian et al. 2011).

$$
\dot{v}_{d}=\frac{\frac{F C_{d} \times 11,007}{100}}{1180}
$$

Eq. (2) presents how the average diesel consumption is calculated using $\rho_{d}$, which is the average density of diesel taken from the literature (Cengel and Boles 2005). The average diesel consumption value is found to be in mass flow rate $\left(\dot{m}_{d}\right)$ as seen from the formula.

$$
\dot{m}_{d}=\dot{v}_{d} \times \rho_{d}
$$

Eq. (3) shows how approximate vehicle LNG consumption is calculated. Again, approximate vehicle LNG consumption is given in mass flow rate form $\left(\dot{m}_{L N G}\right)$ as seen from the formula. Approximate LNG consumption of the vehicle is calculated using the rate of equivalent heating value of diesel and equivalent heating value of LNG $\left(r_{H V, L N G / d}\right)$. Arithmetic means of lower heating values and higher heating values for both diesel and LNG were used in this equivalent rate.

$$
\dot{m}_{L N G}=\dot{m}_{d} \times r_{H V, L N G / d}
$$

Eq. (4) gives the formula of how to calculate the cooling capacity of the LNG gasification process as in the following. Here, $\dot{Q}_{c}$ is the cooling capacity of the system in W unit. This cooling amount is taken from the air to be blown to the vehicle passenger cabin. As to the $\dot{m}_{L N G}$ in the formula, it is the approximate LNG mass flow rate in $\mathrm{kg} / \mathrm{s}$. And $h_{f g, L N G}$ is the vaporization enthalpy of LNG in $\mathrm{kJ} / \mathrm{kg}$. $h_{f g, L N G}$ value is received from the literature (Cengel and Boles 2005) and placed in to the formula.

$$
\dot{Q}_{c}=\dot{m}_{L N G} \times h_{f g, L N G}
$$

Eq. (5) presents the calculation of AC saving values (\%) of the system at various cooling loads in vehicles. Here, $S_{A C}$ is the saving value in percent, $\dot{Q}_{c}$ is cooling capacity value of the system in $\mathrm{W}$, and $\mathrm{L}_{\mathrm{c}}$ is the cooling load value of the vehicle in W. As $\mathrm{L}_{c}$ values of vehicles are constantly changing according to the number of the occupants, vehicle indoor volumes, and, weather conditions $1000 \mathrm{~W}, 3000 \mathrm{~W}$, and $5000 \mathrm{~W}$ values were selected for determining the $\mathrm{AC}$ saving values at different conditions as also suitable in that of the literature (Meier et al. 2018, Fayazbakhsh and Bahrami 2013, Ruth 1975).

$$
S_{A C}=\frac{\dot{Q}_{c}}{\mathrm{~L}_{c}}
$$

Finally, Eq. (6) gives the last calculation of the analysis, which constitutes how to find COP value of the system at different conditions. $C O P_{R}$ is a performance measuring method of an air conditioning system. In the calculation of this value, the proposed system has been considered as like one of thermoelectric coolers that operate according to the Peltier Effect prensible. Dissimilar to conventional refrigerators and air conditioners, thermoelectric coolers do not include any compressor in their system composition. In a similar manner, the proposed system in this study have no compressor. There is no need for a compressor anyway. LNG is already constantly under 
pressure in the tank. When the LNG pressure is insufficient, which deteriorates the flow, the driver goes to a fuel station and fills the tank of the vehicle with LNG. Therefore, total energy consumption of the proposed system does not include LNG fuel consumption of the engine. The only energy consumption of the system that creates cooling effect is the fan power $\left(P_{f}\right)$, which is required to blow the air throughout the air duct and the LNG evaporator. A fan that have three positions is selected in the proposed system. It consumes $24 \mathrm{~W}, 48 \mathrm{~W}$, and $72 \mathrm{~W}$, respectively from low to high positions. These constant electric fan powers were selected according to the literature (Gendebien 2019), which are suitable for the proposed system.

$$
C O P_{R}=\frac{\dot{Q}_{c}}{P_{f}}
$$

\section{Results}

Table 1 shows LNG flow rate, cooling capacity, COP, and $\mathrm{AC}$ saving variations of LNGVs according to the analysis, conducted for diesel fuel consumption values between 0-60 $\mathrm{L} / 100 \mathrm{~km}$. Increasing fuel consumption in diesel vehicles increases LNG consumption as well. Since the calorific value of LNG is slightly higher than that of diesel, a diesel-powered vehicle will consume slightly more LNG by mass when converted to LNG. According to Table 1, cooling capacity of the system can be as high as more than $2.2 \mathrm{~kW}$, which means the system can carry away $2200 \mathrm{~kJ}$ heat energy from the vehicle cabin to outdoor environment per second. This cooling amount may be sufficient enough for the vehicle using no AC system when the cabin $\mathrm{AC}$ load is up to $1 \mathrm{~kW}$ and the diesel equivalent fuel consumption is over about $25 \mathrm{~L} / 100 \mathrm{~km}$. COP values of the proposed system, on the other hand, are higher than normal AC systems, since the only equipment that consumes energy is the fan itself in the system according to the calculation method. 92.2, 46.1, and 30.7 are the highest COP values of the system, respectively for the fan powers of $24 \mathrm{~W}, 48 \mathrm{~W}$, and $72 \mathrm{~W}$.

Table 1. Approximate variations of LNG consumption, cooling capacity, COP, and AC Saving values according to the analysis

\begin{tabular}{|c|c|c|c|c|c|c|c|c|}
\hline $\begin{array}{r}F C_{d} \\
(\mathrm{~L} / \\
100 \\
\mathrm{~km})\end{array}$ & $\begin{array}{c}\dot{m}_{L N G} \\
(\mathrm{~kg} / \mathrm{s})\end{array}$ & $\dot{Q}_{c}(\mathbf{W})$ & $C O P \underset{@ P_{f}=24 \mathrm{~W}}{R}$ & $C O P \underset{@ P_{f}=48 w}{R}$ & $C O P \underset{@ P_{f}=72 W}{R}$ & $\begin{array}{r}S \underset{\text { S }}{A C} \\
\text { @1 kW load } \\
(\%)\end{array}$ & 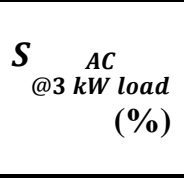 & 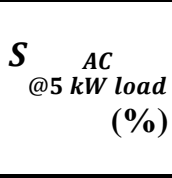 \\
\hline 0 & 0.0000 & 0 & 0.0 & 0.0 & 0.0 & 0 & 0 & 0 \\
\hline 2 & 0.0001 & 74 & 3.1 & 1.5 & 1.0 & 7 & 2 & 1 \\
\hline 4 & 0.0003 & 147 & 6.1 & 3.1 & 2.0 & 15 & 5 & 3 \\
\hline 6 & 0.0004 & 221 & 9.2 & 4.6 & 3.1 & 22 & 7 & 4 \\
\hline 8 & 0.0006 & 295 & 12.3 & 6.1 & 4.1 & 29 & 10 & 6 \\
\hline 10 & 0.0007 & 369 & 15.4 & 7.7 & 5.1 & 37 & 12 & 7 \\
\hline 12 & 0.0009 & 442 & 18.4 & 9.2 & 6.1 & 44 & 15 & 9 \\
\hline 14 & 0.0010 & 516 & 21.5 & 10.8 & 7.2 & 52 & 17 & 10 \\
\hline 16 & 0.0012 & 590 & 24.6 & 12.3 & 8.2 & 59 & 20 & 12 \\
\hline 18 & 0.0013 & 664 & 27.6 & 13.8 & 9.2 & 66 & 22 & 13 \\
\hline 20 & 0.0014 & 737 & 30.7 & 15.4 & 10.2 & 74 & 25 & 15 \\
\hline 22 & 0.0016 & 811 & 33.8 & 16.9 & 11.3 & 81 & 27 & 16 \\
\hline 24 & 0.0017 & 885 & 36.9 & 18.4 & 12.3 & 88 & 29 & 18 \\
\hline 26 & 0.0019 & 958 & 39.9 & 20.0 & 13.3 & 96 & 32 & 19 \\
\hline 28 & 0.0020 & 1032 & 43.0 & 21.5 & 14.3 & 103 & 34 & 21 \\
\hline 30 & 0.0022 & 1106 & 46.1 & 23.0 & 15.4 & 111 & 37 & 22 \\
\hline 32 & 0.0023 & 1180 & 49.2 & 24.6 & 16.4 & 118 & 39 & 24 \\
\hline 34 & 0.0025 & 1253 & 52.2 & 26.1 & 17.4 & 125 & 42 & 25 \\
\hline 36 & 0.0026 & 1327 & 55.3 & 27.6 & 18.4 & 133 & 44 & 27 \\
\hline 38 & 0.0028 & 1401 & 58.4 & 29.2 & 19.5 & 140 & 47 & 28 \\
\hline 40 & 0.0029 & 1475 & 61.4 & 30.7 & 20.5 & 147 & 49 & 29 \\
\hline 42 & 0.0030 & 1548 & 64.5 & 32.3 & 21.5 & 155 & 52 & 31 \\
\hline 44 & 0.0032 & 1622 & 67.6 & 33.8 & 22.5 & 162 & 54 & 32 \\
\hline 46 & 0.0033 & 1696 & 70.7 & 35.3 & 23.6 & 170 & 57 & 34 \\
\hline 48 & 0.0035 & 1769 & 73.7 & 36.9 & 24.6 & 177 & 59 & 35 \\
\hline 50 & 0.0036 & 1843 & 76.8 & 38.4 & 25.6 & 184 & 61 & 37 \\
\hline 52 & 0.0038 & 1917 & 79.9 & 39.9 & 26.6 & 192 & 64 & 38 \\
\hline 54 & 0.0039 & 1991 & 82.9 & 41.5 & 27.6 & 199 & 66 & 40 \\
\hline 56 & 0.0041 & 2064 & 86.0 & 43.0 & 28.7 & 206 & 69 & 41 \\
\hline 58 & 0.0042 & 2138 & 89.1 & 44.5 & 29.7 & 214 & 71 & 43 \\
\hline 60 & 0.0043 & 2212 & 92.2 & 46.1 & 30.7 & 221 & 74 & 44 \\
\hline
\end{tabular}




\section{Conclusion}

Air conditioning systems have a significant contribution to energy consumption in conventional vehicles. LNG powered vehicles, however, have a potential of cooling down of the vehicle cabin by evaporation of LNG while feeding the engine as fuel. Air conditioning without conventional AC system in LNG powered vehicles has been theoretically investigated and analyzed in this study. The results of the study can be concluded show that the system can supply sufficient cooling especially in higher fuel consumption and lower cabin AC load. Vehicles like trucks or lorries that have lower indoor volume and higher fuel consumption values may be the best candidates for this proposed system.

\section{References}

Akar, M.A., Kekilli, E., Bas, O., Yildizhan, S., Serin, H. and Ozcanli, M., (2018) "Hydrogen enriched waste oil biodiesel usage in compression ignition engine", International Journal of Hydrogen Energy, 43, 38, 1804618052 .

Cengel, Y.A. and Boles, M.A., (2005) "Thermodynamics: An Engineering Approach”, 5th ed., McGraw-Hill, New York.

Ciniviz, M. and Köse, H., (2011) "The use of hydrogen in internal combustion engine: a review". International Journal of Automotive Engineering and Technologies, 1.

Deng, S., Jin, H., Cai, R., Lin, R., (2004) "Novel cogeneration power system with liquefied natural gas (LNG) cryogenic exergy utilization", Energy, 29, 4, 497-512.

Dincer, I., (2007) "Environmental and sustainability aspects of hydrogen and fuel cell systems", International Journal of Energy Research, 31, 1, 29-55.

Dispenza, C., Dispenza, G., La Rocca, V., Panno, G., (2009a) "Exergy recovery during LNG regasification: electric energy production-Part one", Appl Therm Eng, 29, 2, 380387.

Dispenza, C., Dispenza, G., La Rocca, V., Panno, G., (2009b) "Exergy recovery during LNG regasification: electric energy production - part two", Appl Therm Eng, 29, 2, 388-399.

Fayazbakhsh M.A. and Bahrami, M., "Comprehensive Modeling of Vehicle Air Conditioning Loads Using Heat Balance Method", SAE International, 2013-01-1507.

Gendebien, S., Parthoens, A., Lemort, V., (2019) "Investigation of a single room ventilation heat recovery exchanger under frosting conditions: Modeling, experimental validation and operating strategies evaluation", Energy and Buildings, 186, 1-16.

Jan, S., Ireneusz, S., (2009) "Utilization of the cryogenic exergy of liquid natural gas (LNG) for the production of electricity", Energy, 34, 7, 827-837.

Javani, N., Dincer, I., Naterer, G.F., (2012) “Thermodynamic analysis of waste heat recovery for cooling systems in hybrid and electric vehicles", Energy, 46, 1, 109-116
Khayyam, H., (2013) "Adaptive intelligent control of vehicle air conditioning system”, Applied Thermal Engineering, 51, 1154-1161.

Lambert, M.A., Jones, B.J., (2006) “Automotive adsorption air conditioner powered by exhaust heat. Part1: conceptual and embodiment design", Journal of Automobile Engineering, 220, 959-972.

Linder, M., Mertz, R., Laurien, E., (2010) "Experimental results of a compact thermally driven cooling system based on metal hydrides", International Journal of Hydrogen Energy, $35,14,7623-7632$.

Liu, Y., Guo, K., (2011) "A novel cryogenic power cycle for LNG cold energy recovery”, Energy, 36, 5, 2828-2833.

Marachlian, J., Benelmir, R., El Bakkali, A., Olivier, G., (2011) "Exergy based simulation model for vehicle HVAC operation”, Applied Thermal Engineering, 31, 5, 696-700.

Meier, K., Kurtz, C., Weckerle, C., Hubner, M., Bürger, I., (2018) "Air-conditioning system for vehicles with on-board hydrogen", Applied Thermal Engineering, 129, 1150-1159.

Pacheco, F.A., Martins, M.E.S., Zhao, H., (2013) "New European Drive Cycle (NEDC) simulation of a passenger car with a HCCI engine: Emissions and fuel consumption results", Fuel, 111, 733-739.

Popov, D., Fikiin, K., Stankov, B., Alvarez, G., Youbi-Idrissi, M., Damas, A., Evans, J., Brown, T., (2019) "Cryogenic Heat Exchangers for Process Cooling and Renewable Energy Storage: A Review", Applied Thermal Engineering.

Randaxhe, F., Lemort, V., Lebrun, J., (2015) "Global Optimization of the Production and the Distribution System for Typical European HVAC Systems", Energy Procedia, $78,2452-2457$.

Ruth, D.W., (1975) "Simulation of modelling of automobile comfort cooling requirements", ASHRAE Journals, 53-55.

Tüccar, G., Tosun, E., Özcanlı, M. and Aydın, K., (2013) "Possibility of Turkey to transit Electric Vehicle-based transportation", International Journal of Automotive Engineering and Technologies 2: 64-69.

Welstand, J., Haskew, H., Gunst, R., and Bevilacqua, O., "Evaluation of the Effects of Air Conditioning Operation and Associated Environmental Conditions on Vehicle Emissions and Fuel Economy," SAE Technical Paper 200301-2247. 